\title{
Recurrent Infections in a Patient with Multiple Myeloma
}

\author{
Sanjay Kini ${ }^{1}$ Aravind Shanbhag ${ }^{2}$ Sachin Chandramohan ${ }^{1}$

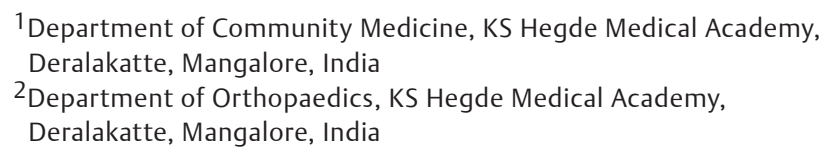 \\ J Health Allied Sci NU 2019;9:81-84
}

Address for correspondence Sanjay Kini, Department of Community Medicine, KS Hegde Medical Academy, Deralakatte, Mangalore 575018, India (e-mail: sanjaykini2010@gmail.com).

\begin{abstract}
Keywords

- multiple myeloma

- anemia

- $\beta 2$-microglobulin

An 80-year-old woman with recurrent urinary tract infection presented to the orthopaedic OPD at KS Hegde Memorial Health Center, Bailur, with gradual onset of generalized weakness, fatigue, anorexia, musculoskeletal pain, and particularly severe backache. The patient was diagnosed to have anemia but renal function tests were normal. X-ray spine showed multiple compression fractures. Serum electrophoresis confirmed the diagnosis of multiple myeloma. In an elderly patient with myalgia, anemia, and recurrent infections, the differential diagnosis of multiple myeloma should be kept in mind as it is often missed by clinicians.
\end{abstract}

\section{Introduction}

Malignant proliferation of plasma cells producing a monoclonal paraprotein characterizes multiple myeloma. Hypocalcaemia, hyperviscosity, renal failure, and bone pains/fractures are some of the typical presentations. The malignant proliferation of plasma cells in bone marrow can be detected by monoclonal protein in the blood or urine, and dysfunction of associated organs. Depending on the absence or presence of an organ lesion or dysfunction of the affected organ tissue, it is classified as asymptomatic or symptomatic. The patient has better prognosis especially in the early stages, where the presentation may vary, which makes the diagnosis difficult. ${ }^{1-4}$ Multiple myeloma constitutes $1 \%$ of neoplastic diseases and $13 \%$ of hematologic cancers. ${ }^{2,4,5}$ The adjusted annual age incidence is 5.6 cases per 100,000 people in the Western countries. ${ }^{1}$ Solitary plasmacytomas and multiple myeloma can be thought of as a spectrum of disease, which ranges from localized clonal plasma cell infiltration to multiple extramedullary lesions, and osseous forms typically progress to multiple myeloma. Multiple myeloma is the most common primary osseous malignancy in adults, typically between the ages of 50 and 70 years, and it is more likely to affect men. ${ }^{6,7}$

The age of diagnosis of multiple myeloma is on an average 70 years-patients under the age of 35 years constitute $35 \%, 26 \%$ are in the range of 65 to 74 years, and patients above 75 years of age constitute $37 \% .^{1,2}$ Polyclonal hypogammaglobulinemia is the main reason for the increased risk of infection in patients with multiple myeloma. ${ }^{1,5}$ Reduction of CD4+ T cells, functional impairment of the natural killer cells, abnormalities in the complement system, and occasional granulopenia are other reasons for mortality in patients with multiple myeloma. ${ }^{15,8}$ When compared with a patient who is hospitalized for any other reasons the risk of infection is 7 to 15 times more in a patient with the above risk factors. ${ }^{1,5,8}$ The presence of at least $10 \%$ plasma cells in the bone marrow sample and the presence of monoclonal protein in serum or urine confirm the diagnosis of multiple myeloma. The presence of $30 \%$ plasma cells or evidence of plasmacytoma in the bone marrow points the diagnosis toward nonsecretory myeloma. ${ }^{4}$

\section{Case Presentation}

An 80-year-old woman presented to the orthopaedic OPD at KS Hegde Memorial Health Centre, Bailur, with complaints of lower back ache. On examination there was kyphosis and spinal movements were painful. X-ray spine showed multiple compression fractures. Blood investigations done in our laboratory showed Hb $9.1 \mathrm{~g} / \mathrm{dL}$, TC 8200, DC: P-78, L-18, E-7, ESR 98, serum creatinine $0.9 \mathrm{mg} / \mathrm{dL}$, serum calcium $7.3 \mathrm{mg} / \mathrm{dL}$. Patient was treated with Inj. Arachitol deep im once in 15 days, tablet Shelcal-CT $500 \mathrm{mg}$ bd. After 1 month the patient again came back with similar complaints restricting her activities
Copyright (C2019 Nitte University (Deemed to be University)
License terms

(요 (1) $\odot$ 
of daily living. Patient was admitted and detailed investigations were done by sending the blood samples to an outside sophisticated laboratory. The details of investigation are given as below

(-Tables 1-3; - Figs. 1-3)

Patient was then advised to consult medical oncologist. But the patient party was reluctant to seek higher treatment because of patient's age, terminal stage of disease, and the financial constraints and the patient was discharged against medical advice.

\section{Past History}

Patient had similar complaints of low back ache for which she had consulted at the orthopaedic OPD in our health center, two years back. On examination, there was kyphosis and tenderness over the LS spine; X-ray showed multiple osteoporotic compression fractures. Blood investigations-serum calcium $10.1 \mathrm{mg} / \mathrm{dL}$ and ALP $285 \mathrm{IU} / \mathrm{L}$. Patient was treated with Inj. Zolantronic acid, tablet Shelcal-CT and analgesics. Patient also had complains of mass per vagina and white discharge per vagina. Urine analysis showed pus cells 15-20/hpf, RBC $1-2 / \mathrm{hpf}$, and epithelial cells $10-15 / \mathrm{hpf}$. She was referred to a gynecologist and was treated conservatively.

\section{Discussion}

One of the main reasons for the development of serious infections in immune-competent patients diagnosed with multiple myeloma is marked hypergammaglobulinemia which is caused by clonal proliferation in bone marrow. The leading cause of mortality in these patients of multiple myeloma is the severe episodes of infections ranging from $0.8 \%$ to $2.2 \%$ of the total multiple myeloma diagnosis every year. Bacterial infections associated with lung and urinary tracts are the most common infections seen in these patients. However, fungal and viral infections are also reported. ${ }^{1,8}$ With the exception of patients with clonal proliferation in the adjacent bone the physical examination in these patients is usually normal. Destruction of bone, bone fractures, and pain are some of the manifestations of clonal proliferation. Anemia, hypercalcemia, renal failure, susceptibility to infection, coagulation problems, neurologic symptoms, and vascular problems due to hyperviscosity are some of the important features seen in these patients.

Looking at the present case, we had a patient with multiple musculoskeletal pain and urinary tract infection with white discharge per vagina. She was treated with broad-spectrum antibiotic like tablet metronidazole. But the patient continued to have symptoms of urinary tract infection (UTI) and WDPV. The presence of at least one of seven possible manifestations which occurs due to organ or tissue damage due to proliferating tumor is one of the important prerequisite for the diagnosis of symptomatic multiple myeloma.

1. Anemia with a decrease in hemoglobin of at least $2 \mathrm{~g} / \mathrm{dL}$ compared with the normal value, or a hemoglobin below $10 \mathrm{~g} / \mathrm{dL}$.

2. Hypercalcemia greater than $10 \mathrm{mg} / \mathrm{L}$ (0.25 mmol/L) above normal or an absolute number greater than $110 \mathrm{mg} / \mathrm{dL}$ (2.75 mmol/L) of serum calcium.

3. Osteolytic lesions, osteoporosis, or compression fractures with no attributable cause.

4. Renal failure, with creatinine of more than $2 \mathrm{mg} / \mathrm{dL}$ or $173 \mathrm{mmol} / \mathrm{L}$.

5. Symptomatic hyperviscosity.

6. Amyloidosis.

7. Recurrent bacterial infections ( $>2$ severe episodes that required hospitalization over a period of 12 months).

It is very important to look into these abnormalities because without the signs of organ damage, the asymptomatic forms of multiple myeloma will require only conservative treatment or no treatment and only regular monitoring. The international system of stratification is used to state prognosis and decide proper management. According to the level of serum protein and $\beta 2$ level the stratification system divides multiple myeloma in three stages ${ }^{1,2,9,10}$

Stage I: serum $\beta 2$-microglobulin $<3.5 \mathrm{mg} / \mathrm{L}$, serum albu$\min \geq 3.5 \mathrm{~g} / \mathrm{dL}$.

Stage II: serum $\beta 2$-microglobulin, $<3.5 \mathrm{mg} / \mathrm{L}$, plus serum albumin $<3.5 \mathrm{~g} / \mathrm{dL}$; or $\beta 2$-microglobulin of 3.5 to $<5.5 \mathrm{mg} / \mathrm{L}$, irrespective of serum level of serum albumin.

Stage III: serum $\beta 2$-microglobulin $\geq 5.5 \mathrm{mg} / \mathrm{L}$.

In the present case the laboratory test report revealed normocytic normochromic anemia and hypoalbuminemia. Our patient also showed an increase in $\beta 2$-microglobulin concentrations (0.6) which are indicative of high tumor burden but the renal parameters were normal, which is generally elevated in patients of multiple myeloma which is indicative of renal failure and is one of the main predictors of disease progression. ${ }^{1,8}$ With conventional chemotherapy, the median survival does not exceed four years currently.,10 Our patient was at stage III multiple myeloma as the levels of $\beta 2$-microglobulin greater than $5.5 \mathrm{mg} / \mathrm{L}$. Induction therapy, followed by high dose therapy and autologous hematopoietic stem cell transplant is the first line of therapy in these patients. ${ }^{5}$ However, because of patient's age, terminal stage of disease and the financial constraints the patient party were reluctant to seek

Table 1 Serum protein electrophoresis

\begin{tabular}{|l|l|l|l|l|}
\hline Fractions & $\%$ & Reference $\%$ & Concentration & Reference concentration \\
\hline Albumin & 42.1 & $55.8-66.1$ & 3.3 & $3.6-5.4$ \\
\hline Alpha 1 & 6.9 & $2.9-4.9$ & 0.5 & $0.2-0.4$ \\
\hline Alpha 2 & 12.7 & $7.1-11.8$ & 1.0 & $0.5-1.0$ \\
\hline Beta 1 & 6.5 & $4.7-7.2$ & 0.5 & $0.3-0.6$ \\
\hline Beta 2 & 7.9 & $3.2-6.5$ & 0.6 & $0.2-0.5$ \\
\hline Gamma & 23.9 & $11.1-18.8$ & 1.9 & $0.7-1.5$ \\
\hline
\end{tabular}


Table 2 Detailed hematologic parameters

\begin{tabular}{|l|l|l|l|}
\hline Parameter & Result & Units & Limit \\
\hline WBC & 9.26 & $10^{3} / \mu \mathrm{L}$ & $4.00-11.00$ \\
\hline Neutrophils & 6.09 & $10^{3} / \mu \mathrm{L}$ & $2.00-7.50$ \\
\hline Lymphocytes & 2.37 & $10^{3} / \mu \mathrm{L}$ & $1.30-4.00$ \\
\hline Monocytes & 0.52 & $10^{3} / \mu \mathrm{L}$ & $0.15-1.40$ \\
\hline Eosinophils & 0.18 & $10^{3} / \mu \mathrm{L}$ & $0.00-0.60$ \\
\hline Basophils & 0.10 & $10^{3} / \mu \mathrm{L}$ & $0.00-0.15$ \\
\hline Neutrophils \% & 65.8 & $\%$ & $40.0-75.0$ \\
\hline Lymphocytes \% & 25.6 & $\%$ & $21.0-40.0$ \\
\hline Monocytes & 5.6 & $\%$ & $3.0-14.0$ \\
\hline Eosinophils $\%$ & 1.9 & $\%$ & $0.0-6.0$ \\
\hline Basophils \% & 1.1 & $\%$ & $0.0-2.0$ \\
\hline RBC & 3.87 & $10^{5} / \mu \mathrm{L}$ & $4.00-5.50$ \\
\hline Hb & 10.9 & $\mathrm{~g} / \mathrm{dL}$ & $12.0-17.4$ \\
\hline HCT & 32.5 & $\%$ & $36.0-52.0$ \\
\hline MCV & 84.2 & $\mathrm{fL}$ & $76.0-96.0$ \\
\hline MCH & 28.2 & $\mathrm{pg}$ & $27.0-32.0$ \\
\hline MCHC & 33.5 & $\mathrm{~g} / \mathrm{dL}$ & $30.0-35.0$ \\
\hline RDWsd & 27.7 & $\mathrm{fL}$ & $46.0-59.0$ \\
\hline RDWcV & 12.6 & $\%$ & $0.0-16.0$ \\
\hline PLT & 301 & $10^{3} / \mu \mathrm{L}$ & $150-450$ \\
\hline PCT & 0.24 & $\%$ & - \\
\hline MPV & 8.0 & $\mathrm{fL}$ & 15.0 \\
\hline PDWsd & 19.1 & $\mathrm{fL}$ & - \\
\hline PDWcv & 37.6 & $\%$ & - \\
\hline PLCR & 30.65 & $10^{3} / \mu \mathrm{L}$ & - \\
\hline PLCC & 92 & & - \\
\hline & & $\%$ & \\
\hline
\end{tabular}

Table 3 Other relevant blood investigations

\begin{tabular}{|l|l|l|l|}
\hline Test & Result & Unit & Range \\
\hline ESR & 102 & $\mathrm{~mm} / \mathrm{hr}$ & $0-40$ \\
\hline Alkaline phosphatase & 88 & $\mathrm{IU} / \mathrm{L}$ & $38-94$ \\
\hline Bence-Jones proteins & Positive & - & - \\
\hline
\end{tabular}

Fig. 1 Serum electrophoresis. 


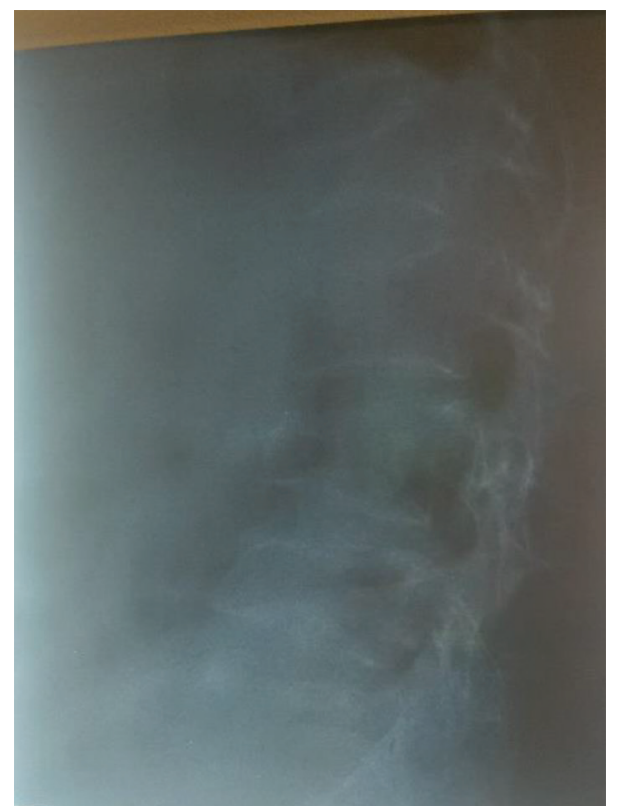

Fig. 2 X-ray spine showing multiple compression fracture.

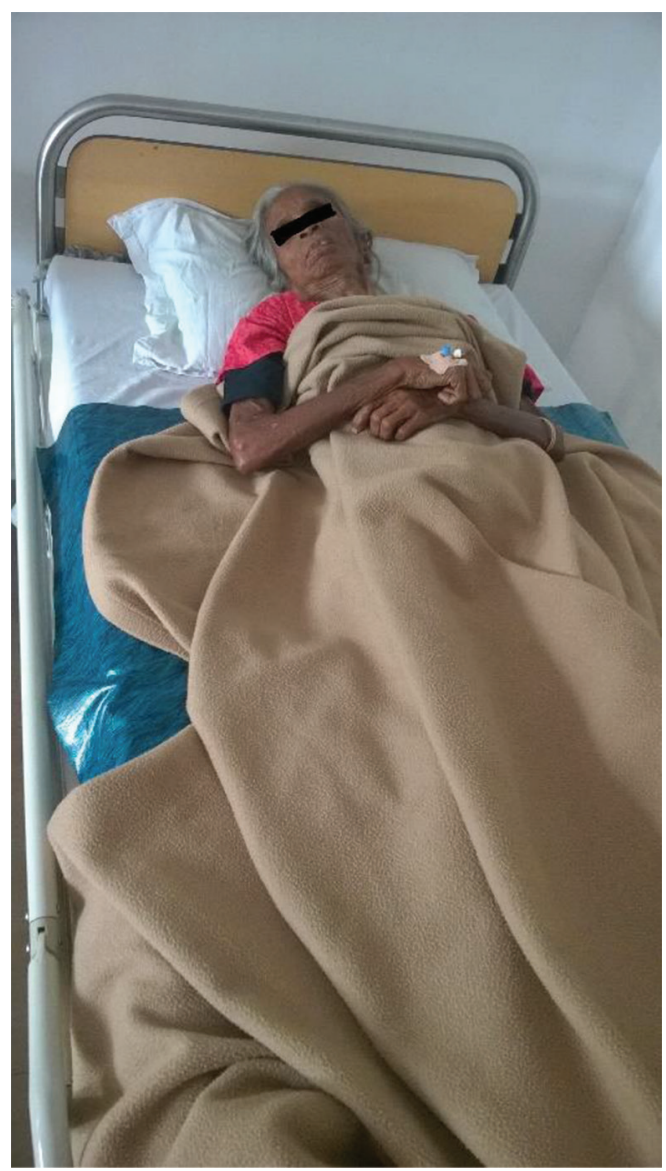

Fig. 3 Patient of multiple myeloma admitted at the health center. treatment at higher center. Age is not only an important factor for the survival of the patient, but also for chemotherapy tolerance. ${ }^{11}$ It has been observed that the survival rate is 50 months in a patient below 65 years of stage II disease, whereas it is only 37 months in a patient above 65 years. ${ }^{5}$ The treatment of choice in this group of patients is the new drugs, such as bortezomib, thalidomide, or lenalidomide, in combination with traditional chemotherapy. ${ }^{15,8,12}$ Significant improvement in the complete remission rate and the overall survival has been observed with the use of these drugs. ${ }^{12}$ Mepfalan or high doses of dexamethasone combined with one of the new drugs as thalidomide or bortezomib has been used as classical treatment schemes in the induction therapy of these patients. ${ }^{8,13}$

\section{Conflict of Interest}

None.

\section{References}

1 Videa-Irias EO, Caballero A, Erazo D, Medina S. Multiple myeloma, a patient with multiple infections: a case report. Arch Cancer Res 2016;4-3

2 Palumbo A, Anderson K. Multiple myeloma. N Engl J Med 2011;364(11):1046-1060

3 Kyle RA. Remstein ED. Therneau TM. Dispenzieri A. Kurtin PJ. Hodnefield JM. et al. Clinical course and prognosis of smoldering (asymptomatic) multiple mieloma. N Engl J Med 2007;356:2582-2590

4 Bladé J. Clinical practice. Monoclonal gammopathy of undetermined significance. N Engl J Med 2006;355(26):2765-2770

5 David GA. Guíasmexicanas de diagnóstico y recomendacionesterapéuticas para mielomamúltiple. ReviHematologia 2009;11:40-62

6 Ames J, Al-Samaraee A, Takahashi T. Extraosseous multiple myeloma: case report of presentation in the lower extremity soft tissues with literature review. Case Rep Radiol 2017;2017:9159035

7 Hanrahan CJ, Christensen CR, Crim JR. Current concepts in the evaluation of multiple myeloma with MR imaging and FDG PET/CT. Radiographics 2010;30(1):127-142

8 Ramón GS, María VM. Mielomamúltiple, Servicio de Hematología. Hospital Universitario de Salamanca. Centro de InvestigacióndelCáncer, Salamanca. España. Med Clin (Barc) 2007;129:104-115

9 Serra-Valdés M, Alfaro-Amigó A, Viera-García M. Síndrome de hiperviscosidadcomopresentación del myeloma múltiple. Reporteun de caso. Revista Finlay 2013;3:4 (revista en Internet)

10 Barlogie B, Mitchell A, van Rhee F, Epstein J, Morgan GJ, Crowley J. Curing myeloma at last: defining criteria and providing the evidence. Blood 2014;124(20):3043-3051

11 Heinz L, Brian GM, Vanessa B, Ingemar T, Kyle RA, Blade J, et al. Myeloma in patients younger than age 50 years presents with more favorable features and shows better survival: an analysis of 10,549 patients from the International Myeloma WorkingGroup. Blood 2008;111:4039-4047

12 Moreau P, Attal M, Facon T. Frontline therapy of multiple myeloma. Blood 2015;125(20):3076-3084

13 Bladé J, Rosiñol L, Fernández de Larrea C. How I treat relapsed myeloma. Blood 2015;125(10):1532-1540 